\title{
Too narrow-minded about energy?
}

THE gilt text inscribed around the ceiling of Church House, Westminster, speaks of "true light", "lending radiance" and "enduring in the heat" (admittedly "of the conflict"). A highly appropriate setting for $\mathrm{Mr}$ Anthony Wedgwood Benn's National Energy Conference last week, to which 470 were invited and at which 56 spoke.

Let it first be said that all those reasonable doubts that such an event could take place without degenerating into a shambles turned out to be unjustified, for which great credit to $\mathrm{Mr}$ Benn's chairmanship (and not least his restraint in not intervening in the debate at all himself) and to the speakers who never once exceeded their time limit. But there is a world of difference between a well-ordered debate and open government; has $\mathrm{Mr}$ Benn done anything beyond ensure that all interested parties had a six-minute airing of the views?

There is no doubt the meeting was valuable in mutual education terms; almost all attenders had at least the courtesy to sit and listen to all contributions rather than break up into factions in the corridor to discuss heaven knows what. But what can Mr Benn and his staff do as a result of it all that he couldn't have done the day before? for it can reasonably be assumed that he, as an exponent of open government, will have been familiar with all the points raised-even Sir Brian Flowers warning that the Royal Commission on Environmental Pollution will raise serious questions about living with plutonium, and even $\mathrm{Mr}$ Enoch Powell's brilliant oratory against any form of energy policy-making as ill-conceived and pernicious.

That Mr Benn and his department will have learnt little new from his conference is really the result of attempting to get too many things in focus in one day. The most incongruous of them was the question of disconnections of electricity and gas for non-payment. This was a bandwagon tailor-made for union leaders to jump on to, and although it provided some stirring talk, it managed to confuse a conference convened to talk about energy policy by diverting attention to matters of social policy, which should not be within Mr Benn's terms of reference.

Another structural weakness of the day was the lack of a challenging position paper. Before the conference everyone had been flooded with documents representing the positions of every conceivable interest. but the Department of Energy had, it seemed, decided to maintain a low profile. Its agenda and discussion paper was little more than a list of subject headings-and even that was largely ignored by speakers.

In hindsight, this was probably unfortunate. What was really needed was a major presentation, perhaps an hour in length and certainly well illustrated (not a slide was shown all day!), skilfully aimed at raising the more provocative issues and setting a more definite tone for the day. Perhaps Mr Benn will try this, as he undoubtedly has plans for future, smaller gatherings.

But whatever the next move is that Mr Benn has up his sleeve, his eventual plans for the gas industry are likely to provide the most sensitive litmus of true commitment to "open government". When Lord Ryder stood up to dismiss as economically senselesss the calls for a competitive restrictive tariff on North Sea gas, he was not only supporting the gas industry itself, but also voicing the majority opinion among institutionally disinterested energy experts. Lord Ryder's reference to a 1976 version of the mad hatter's tea party, and his warning of the dangers of a "wretched cartel with coal and electricity" will ensure one thing at least. If $\mathrm{Mr}$ Benn, often accused of a fondness for dogmatism, eventually opts for the recommendations of his political advisers and thus weighs down the nation's only economically sound energy industry, he will need a convincing case to defend himself against allegations of blind adherence to doctrine. While some sympathy must be felt for the coal and electricity chiefs, struggling through a difficult period, on current analyses a gas tax provides a poor solution to their own dilemma, and a poorer answer to the nation's broader, long-term energy problems.

The difficulties of the gas industry perhaps underline a disturbing thread running through the day (and conceivably the result of no strong position paper): the narrowmindedness of most participants. An unspoken assumption seemed to be that self-sufficiency in Britain was the aim and if we talked about energy in any international forum at all (and almost all didn't) it was to be from a position of independence. This was the much more explicit objective, two years ago, of Project Independence in the United States. It assumes that in the long run no foreigners are trustworthy. There is much danger in such chauvinism, which may go down well in some political circles but which could lead to some ridiculously expensive decisions being made in pursuit of xenophobia.

Britain in general depends heavily on importing and exporting and is inevitably vulnerable to the capriciousness of suppliers of raw materials and food. But foreign policy, recognising no alternative to large-scale importing, is aimed at maintaining the appropriate good relations. Should energy be an exception to be protected by vast expenditures in research, development and implementation? This is one issue we would like to hear Mr Benn speak more of. 